\title{
Editorial
}

\section{Introduction to the Special Issue on Ecological Civilization and Environmental Governance}

This special issue marks the end of the fourth year of publication of our journal. It also marks an extraordinary year in terms of the urgent need for greatly enhanced regulation of the way that humans interact with the natural environment on a global and national basis. It is thus serendipitous that the focus of this special issue is a discussion of the concept of ecological civilization and environmental governance. ${ }^{1}$ Ecological civilization first emerged in the scientific literature in the 1980 s, and has since that time attracted a great deal of academic comment from across the disciplines, including environmental law and political science.

At the outset, we can recognise that ecological civilization can be broadly equated with the internationally accepted concept of 'sustainable development'. Sustainable development has, of course, been part of China's environmental lexicon since 1994, when China's Agenda 21 was published. ${ }^{2}$ As noted by Prof. QIN Tianbao: 'In 2012, China put forward the concept "eco-civilization", which is regarded as the Chinese expression of sustainable development, further promoting the development of the principle of Sustainable Development. ${ }^{3}$ Ecological civilization certainly incorporates the

1 This special issue forms part of a project entitled 'Ecological Civilization and International Environmental Law' led by Ben Boer and colleagues at the Research Institute of Environmental Law, School of Law, Wuhan University, approved by the Chinese Ministry of Education in 2015 (No. 16JJD820012).

2 State Council of the People's Republic of China, 'China's Agenda 21: White Paper on China's Population, Environment and Development in the 21st Century' (1994).

3 Tianbao QIN, 'China and International Rule of Law and Environmental Protection' in Lingliang ZENG and Jiehan FENG (eds) Annual Report on China's Practice in Promoting the International Rule of Law (Social Sciences Academic Press (China) 2015).

(C) BEN BOER, ROWENA CANTLEY-SMITH AND QIN TIANBAO, 2020 | DOI:10.1163/24686042-12340054 
concept of sustainable development; it is also generally consistent with United Nations Resolution A/Res/70/1 of 2015, which sets out the 2030 Agenda for Sustainable Development and the Sustainable Development Goals (SDGs). However, it can also be seen as a deeper concept. It goes beyond the idea of the physical sustainability of human development activities, requiring us to examine the ethical basis of the human relationship to nature and our use of Earth's resources.

In considering the history of the development of the concept of ecological civilization, we can note that President Hu Jintao officially mentioned it in 2007. At that stage, the English-language China Daily remarked: 'It is not a term the Party has coined just to fill a theoretical vacancy in its socialism with Chinese characteristics, but rather a future-oriented guiding principle based on the perception of the extremely high price we have paid for our economic miracle. 4

In 2012, the concept was listed as one of five goals in China's development plan during the 18th National Congress of the Chinese Communist Party. At the Third Plenary Session of the 18th Central Committee in 2013, President XI Jinping stressed that China would implement ecological civilization reforms, by which he meant 'reforms to reconcile contradictions between economic development and the environment. ${ }^{5}$

The concept has become part of Chinese environmental law and policy over the past 8 years. Its close links to the internationally accepted policy of sustainable development is made clear in article 1 of China's 2014 Environment Protection Law, which states:

This Law is formulated for the purpose of protecting and improving the environment, preventing and controlling pollution and other public hazards, safeguarding public health, promoting improvement of ecological civilization and facilitating sustainable economic and socially sustainable development (emphasis added).

However, the scope of ecological civilization is seen to go beyond the traditional understandings of sustainable development, by incorporating cultural

4 'Ecological Civilization,' China Daily, 24 October 2007 <http://www.chinadaily.com.cn/opinion/2007-10/24/content_6201964.htm>.

5 Zhang CHUN, 'China's =New Blueprint for an Ecological Civilization' September 30, 2015, The Diplomat <http://thediplomat.com/2015/og/chinas-new-blueprint-for-an-ecological -civilization/>. 
and political elements into it. ${ }^{6}$ These extra elements might be seen to be confirmed by the fact that the concept was incorporated into the Constitution of the Chinese Communist Party in 2012, and was inserted into the country's Thirteenth Five Year Plan by China's Government in March 2016. ${ }^{7}$ In 2018, the concept was added into the Chinese Constitution. ${ }^{8}$ It would also be expected that the concept will be incorporated into the Fourteenth Five Year Plan in 2021.

The address of President XI Jinpeng to the UN General Assembly in September 2020, echoing some of the themes of his 2015 address to the UN with regard to the SDGs, ${ }^{9}$ indicates China's policy that ecological progress and green thinking is not confined only to China but that it should apply to the rest of the world:

We call on all countries to pursue innovative, coordinated, green and open development for all, seize the historic opportunities presented by the new round of scientific and technological revolution and industrial transformation, achieve a green recovery of the world economy in the

6 As Paul BARRESI stated in our first issue: 'It seeks to transcend the Western model of industrial modernization by basically forming an energy and resource-efficient and environment-friendly structure of industries, pattern of growth and mode of consumption'. Paul A BARRESI, 'The Role of Law and the Rule of Law in China's Quest to Build an Ecological Civilization' (2017) 1(1) Chinese Journal of Environmental Law 1, 9.

7 'The 13th Five-Year Plan for Economic and Social Development of the People's Republic of China (2016-2020)' (Central Compilation \& Translation Press 2016). <https://www.un.org/ development/desa/disabilities/wp-content/uploads/sites/15/2019/10/China_13th-Five-Yea r-Plan-for-Economic-and-Social-Development-Chapter-66.pdf>. This Plan refers to 'ecological progress', which is often taken to refer to 'ecological civilization', as Hanson points out: 'Ecological civilization sometimes is translated as ecological progress. This form can be thought of as improvements in the present state of natural capital-much the same as thinking about improvements in social progress and economic progress. Ecological progress is often associated with political aspects of ecological civilization since both national and local leaders are understandably anxious to show how their actions are valuable to citizens.' Arthur HANSON. Ecological Civilization in the People's Republic of China: Values, Action, and Future Needs (Asian Development Bank December 2019) AD в East Asia Working Paper Series, No 21, $11<$ https://www.adb.org/sites/default/files/publication/545291/eawp-o21-ecologicalcivilization-prc.pdf $>$.

8 Constitution of the People's Republic of China as amended in 2018, Preamble and art 89(6) <http://www.gov.cn/guoqing/2018-03/22/content_5276318.htm>.

9 Nikhil SONNAD, 'Xi Jinping's first UN address' Quartz September 29, $2015<\mathrm{https://}$ qz.com/512886/read-the-full-text-of-xi-jinpings-first-un-address>. 
post-COvid era and thus create a powerful force driving sustainable development. ${ }^{10}$

Certainly at a national level, there are many jurisdictions where the environmental legal mechanisms are very weak, with many of them incapable of addressing the implementation of the SDGs. ${ }^{11}$ Environmental law has a vital role to play in order for the culture of ecological civilization to be more broadly accepted and truly successful in terms of redressing the balance between national economic demands and the need for enhanced environment protection. However, comprehensive law reform is needed concerning the implementation of international environmental conventions, including those on chemicals, marine pollution, the conservation of biological diversity and on climate change, to name just a few areas.

The rolling out of China's Belt and Road Initiative (BRI) in the past decade makes such law reform all the more important for host BRI countries. As stated in a recent publication: ${ }^{12}$

The synergistic development of Green Belt and Road and the 2030 Agenda for Sustainable Development will facilitate sustainable development in the region, help developing countries to get rid of the mindset of 'developing first and taking green issues in a second stage', and making BRI a platform for ecological civilization construction and the building of a green community of shared destiny.

If the concept of ecological civilization were to be more widely adopted around the world, it would demand a critical examination of all aspects of international environmental law to ensure that more holistic integrated and consistent legal frameworks are generated with a view to drafting much more robust 'green legislation'. In contemplating the practical application of the concept, some fundamental legal matters remain to be resolved. The most basic one is a broadly agreed definition of ecological civilization suitable for adoption in national level legislation, and at international level where appropriate. The second matter is the generation of a set of ecological civilization

10 Xi Jinping's speech at the General Debate of the $75^{\text {th }}$ session of the United Nations General Assembly, 23 September 2020 <https://news.cgtn.com/news/2020-o9-23/Full-text-Xi -Jinping-s-speech-at-General-Debate-of-UNGA-Uo7X2dn8Ag/index.html>.

11 United Nations, Transforming Our World: A New Agenda for Global Action and the 2015 Sustainable Development Goals (A/REs/70/1 2015). <https://sustainabledevelopment. un.org/post2015/transformingourworld $>$.

12 China Council for International Cooperation and Economic Development, Green Belt and Road Initiative (BRI) and the 2030 SDGs: Special Policy Study Report (2019) 1. 
principles that can be readily understood and implemented by government officials, the private sector and the community. ${ }^{13}$

At a national level, for all countries, the incorporation of the concepts underlying ecological civilization would mean taking a close look at environmental and natural resources laws in order to recommend reform of their objectives, scope, definitions, and implementation mechanisms in order to judge whether they are capable of achieving the ideals of ecological civilization.

A variety of the issues concerning the concept of ecological civilization and environmental governance briefly canvassed above are examined in some detail in the six research articles comprising this special issue.

In the first article, 'Ecological Civilization and Legal Norms for Resilient Environmental Governance' Nicholas ROBINSON, one of our international advisory board members and a global doyen in the realm of environmental law, has canvassed the many environmental challenges that the globe faces. The aim of his article is to examine how the principles of ecological civilization can help shape a consensus about restating environmental legal principles generally. This restatement is essential given the fact that many human laws have proven to be manifestly at variance with the natural systems of Earth's biosphere. Disruptions caused by climate change increase and the sixth great extinction of species has ushered in crises in biodiversity. He argues that with environmental degradation becoming worse worldwide, more is required of governments than just again endorsing steps to advance sustainable development. Rather, there is a need for more effective and resilient governmental management. He reminds us of the rich history of attempts to import ecological law into the then USSR, and indicates that there are parallels between the Chinese concept of ecological civilization and the idea of ecological law. He strongly argues that the idea of ecological law should be re-introduced and enhanced by new principles, such as the principle of resilience, which, to date, has been included in several instruments generated over the past few years. ${ }^{14}$

13 A comparable exercise is the inclusion of principles of 'ecologically sustainable development' in many environmental statutes at federal level and in the states and. territories in Australia; see for example, section $3 \mathrm{~A}$ of the Environment Protection and Biodiversity Conservation Act 1999 (Australia), which sets out five such principles; see <https://www .legislation.gov.au/Details/C2O2oCoo291>.

14 IUCN World Declaration on the Environmental Rule of Law (adopted in April 2016 in Rio de Janeiro, Brazil) <https://www.iucn.org/sites/dev/files/content/documents/eng lish_world_declaration_on_the_environmental_rule_of_law_final.pdf $>$. 
He concludes that, potentially, China can contribute greatly to the global debate about Earth's ecological principles of law by sharing its knowledge and understanding of ecological civilization.

In the second article, 'A Global Environmental Pact and Ecological Civilization', Bingyu LIU explores the recent unsuccessful attempt to introduce a new global instrument for the environment into existing international environmental law and considers the potentially important conceptual contribution of 'ecological civilization' to the substance of any future negotiations of this kind. After detailing the drafting of such an instrument, LIU describes the key processes initiated by the UN General Assembly to support investigation into a range of gaps in existing international environmental law, instruments, and governance. While the reports from the UN Secretary General and an ad hoc open-ended working group highlighted the need for greater international cooperation and implementation of existing international environmental law, LIU notes that a new global instrument was not, at that time, recommended by the working group. Her view is that conclusion of such a pact is in any case premature. In supporting this view, LIU refers to the considerable discord between States that emerged during three substantive meetings of a United Nations-appointed ad hoc open-ended working group in early 2019. Nevertheless, she contends that China should assume an active role in any future negotiations for a new global environmental instrument and that this would reflect China's commitment to the development of international environmental law and ecological civilization on a global basis.

In the third article, 'Corporate Environmental Responsibility, Ecological Civilization and a Green BRI', Mengxing LU examines the significance of corporate environmental responsibility for the implementation of the concept of ecological civilization and the 'greening' of China's Belt and Road Initiative (вRI). She addresses growing international concerns that China is using the BRI host countries as new 'pollution havens'. In countering these concerns, she examines the advantages of employing the concept of corporate environmental responsibility to motivate Chinese corporations to strengthen their environmental risk management, including when they are operating and investing in host countries of the BRI. LU's discussion highlights the array of policies and guidelines already introduced by the Chinese government that aim to integrate the concept of ecological civilization and green development into the BRI's implementation. Directed towards Chinese companies, these policies and guidelines require corporate observance of local environmental laws and standards, regardless of where the investment and business activities take place. Despite this, LU draws attention to the difficulties that arise when host countries' 
environmental regulatory frameworks are of a lower standard and more lenient than those that are in effect in China. Whilst concluding that the concept of corporate environmental responsibility can certainly provide added value for the implementation of ecological civilization and a green BRI, she argues that the success of this kind of regulatory approach does not work best as a form of private environmental governance. On the contrary, LU suggests, in certain circumstances, governmental intervention can drive greater understanding of the advantages of ecological civilization and enhanced environmental outcomes along the BRI.

The fourth article, 'Ecological Civilization and Dispute Resolution in the BRI' by Peter CORNE and Vivien ZHU, examines a different but very important aspect of the concept of ecological civilization in the context of the BRI. The authors identify the need to deal with the complexities arising from China's interactions with disparate cultures, ecosystems, societies and their associated laws and local practices as one of the main challenges facing the country in executing the BRI. CORNE and ZHU argue that intrinsic to the concept of ecological civilization is its incorporation of a broad set of culturally derived norms and customs that represent an inclusive approach to cultural and ecological diversity. They advocate the adoption of mediation along the Belt and Road as the primary or 'first line' dispute resolution tool, with a neutral third party acting as a mediator. They argue that as a 'facilitative' rather than an 'adjudicative' process, mediation can steer the parties to the settlement of a dispute related to the environment and natural resources in a way that is consistent with the principles of ecological civilization while respecting the broader concerns of each participant under their respective 'living laws'. The authors maintain that as a 'second line' or alternatively 'parallel line' of dispute resolution, arbitration will continue to be critically important for BRI disputes. A series of measures that will oblige arbitrators to incorporate ecological principles into their deliberations are recommended.

Matthew BAIRD and Brendon THOMAS, in their article 'Greening the BRI in ASEAN', examine how infrastructure projects, particularly investments in road, rail, and energy, can significantly impact ecological integrity and overall environmental quality. They note that the Belt and Road Initiative, given its focus on large-scale infrastructure and energy projects, poses a significant threat to ecosystems in BRI member countries. They argue, however, that these environmental and social risks can nevertheless be assessed and mitigated by using tools such as Environmental Impact Assessment (EIA). The primary aim of the article is to show why it is necessary to apply the concept of ecological civilization to Chinese foreign investment projects in Myanmar and other 
Association of Southeast Asian Nations (ASEAN) member countries. They demonstrate this by examining the EIA process of a large-scale hydropower development project in Myanmar - the Myitsone dam project. Analysis of the project's E IA, they argue, illustrates significant shortcomings for both the public participation process and the overall report's ability to adhere to good practice and include the full extent of project impacts. They assert that projects such as the Myitsone dam, which cause community conflict and environmental and social harm, do not fall within the stated 'win-win-win' objective of the BRI. The article concludes that, unlike the flawed Myitsone process, EIA combined with other requisite public participation processes associated with BRI projects have the potential to foster improved community relations. The authors posit that a green BRI will result in more equitable development in ASEAN, and several significant opportunities to further green the BRI are identified.

In his article, 'China's Ecological Civilization Concept as a Principle of Global Environmental Governance', Paul BARRESI closes this special issue with an examination of the concept of ecological civilization as a principle of global environmental governance. He notes that the most fascinating feature of China's ecological civilization concept is not its goals but 'its explicit embrace of both modern and traditional means as essential for achieving those goals'. He states that this feature of the concept highlights a paradox that would be inherent in its implementation as a principle of global environmental governance in societies where a strong rule of law remains aspirational. Fortunately, he maintains, the ecological civilization concept also seems flexible enough to allow for an implementation strategy with Socratic overtones that would help all societies to learn how to craft blends of both modern and traditional means of building an ecological civilization even in the absence of a strong rule of law.

In Issue 4.1 earlier this year, we noted that a number of significant international meetings on the environment had to be delayed because of the travel restrictions arising from the COVID-19 pandemic. At this stage we can note that the Conference of the Parties for the UN Biodiversity Convention (COP15) is now intended to take place in Kunming, China from 17 to 3 o May 2021. Significantly for the theme of this special issue of CJEL, Ecological Civilization and Environmental Governance, the theme of COP15 will be 'Ecological Civilization: 
Building a Shared Future for All Life on Earth.' ${ }^{15}$ COP15 will be crucial to the development of the post-2021 global biodiversity framework, and for setting goals for global biodiversity between the period 2021 and 2030. Those goals will no doubt take into account the successes and failures of the Strategic Plan for Biodiversity 2011-2020,6 including the Aichi Targets set at the Biodiversity COP in Nagoya, Japan in 2010 as well as the targets set under Sustainable Development Goals 14 (Life under water) and 15 (Life on the Land). It is also anticipated that there will be a number of side meetings that will deal with various aspects of the COVID-19 pandemic, including issues of environment law.

\section{Change of Managing Editor}

Finally, we are delighted to announce that our journal has now appointed a new Managing Editor, Dr Colin MACKIE, Associate Professor, School of Law, University of Leeds, United Kingdom. ${ }^{17}$ Colin has been an Associate Editor of CJEL from the very first issue, and we very much look forward to working with him in this new role. We encourage our readers, and current and potential authors and reviewers to be in touch with Colin with respect to the preparation of articles, reports on recent developments, reviews of books and ideas for topics to be covered in future issues of the journal.

\section{Ben BOER, Rowena CANTLEY-SMITH and QIN Tianbao}

15 UN Biodiversity Conference (СBD COP 15) <http://english.mee.gov.cn/News_service/ media_news/202007/t20200730_79186o.shtml>, and UN Biodiversity Conference (СBD COP 15) International Institute for Sustainable Development (undated) <https://sdg.iisd .org/events/2O2O-un-biodiversity-conference/>.

16 United Nations, 'Convention on Biological Diversity' (1992) <https://www.cbd.int/doc/ legal/cbd-en.pdf>.

17 See Dr Colin MACKIE, University of Leeds School of Law <https://essl.leeds.ac.uk/law/ staff/208/dr-colin-mackie>. 